\title{
Strategies for the dentist management of cancer patients: narrative literature review
}

\begin{abstract}
Aim: To present the dental procedures necessary for the prevention, diagnosis, and treatment of oral toxicities related to cancer treatment.

Material and methods: A narrative literature review was carried out regarding the topics of interest. Articles in Portuguese and English, without the restriction of the year of publication and full text available in the databases Pubmed, Scielo, Cochrane, and Google Scholar were investigated.

Results: Through this search, 100 articles were selected, consisting of 9 systematic reviews, 3 systematic reviews with meta-analysis, 48 literature reviews, 3 randomized clinical trials, 4 prospective cohorts, 12 retrospective cohorts, 5 cross-sectional studies, 2 case-control studies, 5 case reports, 7 expert consensus panels, 1 letter to the editor and 1 qualitative study, published between 1976 and 2020. Dental procedures were classified according to the therapeutic modality (surgery and radiotherapy for head and neck cancer, chemotherapy, hematopoietic stem cell transplantation, and use of antiresorptive medications) and the time of treatment (prior, during, or after each one).
\end{abstract}

Conclusions: The consulted articles were unanimous regarding the need for dental care for cancer patients in the pre, trans, and post-treatment, highlighting the importance of inserting specialized dental surgeons in the oncology patient care team; thus, this professional should act in the prevention, early diagnosis, and treatment of oral toxicities, to minimize their consequences and improve patients' quality of life.

Keywords: dentistry, medical oncology, patient care team, radiotherapy, chemotherapy, hematopoietic stem cell transplantation, antiresorptive medications
Volume 12 Issue 4 - 202I

\author{
Lísia Daltro Borges Alves,' Ana Carolina dos \\ Santos Menezes, 'Ana Maria Dias da Costa,' \\ Fernanda Vieira Heimlich,' Daniel Cohen \\ Goldemberg, ${ }^{2}$ Héliton Spindola Antunes ${ }^{3}$ \\ 'DDS, National Cancer Institute, Brazil \\ 2Ph.D. in Oral Pathology, National Cancer Institute, Brazil \\ ${ }^{3}$ Ph.D. in Oncology, National Cancer Institute, Brazil
}

Correspondence: Héliton Spíndola Antunes, Rua André Cavalcanti, 37- $3^{\mathrm{a}}$ andar-Anexo-Sala II, Bairro de Fátima-CEP: 2023 I-050. Rio de Janeiro, Rio de Janeiro, Brazil, Tel +55 21 32076597, Fax +55 2132076566, Email hspindola@inca.gov.br

Received: July 08, 2021 | Published: July 19, 2021

\section{Introduction}

According to data released by the International Agency for Research on Cancer (IARC) in 2020, cancer will be the second leading cause of premature deaths in most countries including Brazil, only surpassed by cardiovascular diseases. ${ }^{1}$ Cancer is currently considered one of the most significant public health issues and has been increasing in both incidence and mortality in recent years. ${ }^{2}$ According to Bray et $\mathrm{al}^{3}{ }^{3}$, there were 18 million new cases and 9.6 million deaths of cancer worldwide in 2018. In Brazil, in the 2020-2022 triennium, 625,000 new cases of cancer are expected. ${ }^{2}$

Due to the aggressiveness inherent to cancer treatment, patients can present a series of complications, both systemic and local; among these, the mouth may present a number of these intricacies. ${ }^{4}$ In addition to oral mucositis $(\mathrm{OM})$, the dental foci are one of the main causes of systemic infections, since the colonizing microorganisms of the oral microbiota can migrate through the surface of the epithelium and reach the circulation due to loss of epithelial integrity. ${ }^{5,6}$ Consequently, these sources of infections need to be treated or at least controlled before the patient is placed on antineoplastic therapy since the complications generated thereby can imply an increase in morbidity, mortality, and hospitalization costs. ${ }^{4,7,8}$ Thus, the objective of this article is to present the dental procedures necessary for the prevention, diagnosis, and treatment of oral toxicities of cancer treatment.

\section{Material and methods}

This is a narrative literature review, regarding the role of the dental surgeon in the prevention, diagnosis, and treatment of oral toxicities related to cancer treatment. A comprehensive and random search was performed for scientific articles published on the subject in question. Articles available in the Pubmed, Scielo, Cochrane, and Google Scholar databases were investigated in Portuguese and English, without a time interval specification.

The research was conducted using different combinations of the following keywords: "surgery", "chemotherapy", "hematopoietic stem cell transplantation", "antiresorptive medications", "radiotherapy", "oral toxicities", "dental management" and "cancer patients". Full articles that addressed the theme, published in scientific journals, without restriction as to the methodology were included. However, book chapters and abstracts of meetings were excluded.

\section{Results and discussion}

The search resulted in 100 selected articles, consisting of 3 systematic reviews with meta-analysis, 9 systematic reviews, 48 literature reviews, 3 randomized clinical trials, 4 prospective cohorts, 12 retrospective cohorts, 5 cross-sectional studies, 2 case-control studies, 5 case reports, 7 expert consensus panels, 1 letter to the editor and 1 qualitative study, published between 1976 and 2020 .

The articles approach dental care for patients who will be, are being, or have been subjected to surgery and radiotherapy (RT) for head and neck $(\mathrm{H} \& \mathrm{~N})$ cancer, chemotherapy (CT), hematopoietic stem cell transplantation (HSCT), and the use of antiresorptive medications. Dental procedures were classified according to the time of treatment: prior, during, or after each therapeutic modality addressed, when applicable. 


\section{Dental care for patients undergoing head and neck surgery}

Surgery is the main treatment employed for H\&N tumors, usually indicated for initial tumors, but in some cases, replaced by isolated RT. ${ }^{9}$ It is reserved for tumors in which resection with neoplasia-free margins and minimal functional disorder is possible, thus ensuring complete removal of the neoplasia; ${ }^{10}$ even so, it can result in aesthetic disfigurement and significant functionality loss, which can implicate in emotional changes and social interaction impairment. ${ }^{9,11}$ Any H\&N surgery patient must undergo a prior dental checkup. ${ }^{12-14}$ This assessment must include oral hygiene instruction, the removal of infectious foci, and the production of a transurgical palatal obturator, for maxillary surgeries (Table 1).

Table I Dental care for patients undergoing head and neck surgery

\begin{tabular}{|c|c|c|}
\hline & Pre-surgery management & Late post-surgery management \\
\hline Oral hygiene instruction & $\begin{array}{l}\text { The patient must use an extra soft brush a, fluoride } \\
\text { toothpaste, }{ }^{79} \text { and } 0.12 \% \text { chlorhexidine-based } \\
\text { mouthwashes }{ }^{40} \text { in the immediate post-surgery period }\end{array}$ & $\begin{array}{l}\text { Tooth brushing }{ }^{\text {a }} \text { with a soft brush and } \\
\text { fluoride toothpaste }{ }^{79}\end{array}$ \\
\hline Oral environment adequacy & $\begin{array}{l}\text { Treatment of mucosal infections }{ }^{80} \text { and elimination of any } \\
\text { source of trauma }\end{array}$ & Diagnosis of recurrent lesions ${ }^{15}$ \\
\hline Periodontal treatment & $\begin{array}{l}\text { Dental scaling according to conventional dental } \\
\text { standards }{ }^{12,81,82}\end{array}$ & $\begin{array}{l}\text { According to conventional dental } \\
\text { standards }^{82}\end{array}$ \\
\hline Restorative treatment & $\begin{array}{l}\text { Restoration of caries lesions; adjusting or replacing pre- } \\
\text { existing restorations }{ }^{12,83} \text { according to conventional dental } \\
\text { standards, of teeth that are not in the tumor area }\end{array}$ & $\begin{array}{l}\text { According to conventional dental } \\
\text { standards }^{82,83}\end{array}$ \\
\hline Endodontic treatment & $\begin{array}{l}\text { Endodontic treatment according to conventional dental } \\
\text { standards, }{ }^{82} \text { of teeth that are not in the tumor area }\end{array}$ & $\begin{array}{l}\text { According to conventional dental } \\
\text { standards }\end{array}$ \\
\hline $\begin{array}{l}\text { Surgery treatment (teeth or roots } \\
\text { extraction, intraosseous lesions, } \\
\text { periodontal surgery, implants) }\end{array}$ & $\begin{array}{l}\text { According to conventional dental standards, to remove } \\
\text { foci of infection, }{ }^{84} \text { in areas that are not affected by the } \\
\text { tumor; installation of osseointegrated implants for future } \\
\text { prosthetic rehabilitation }{ }^{13} \text { in areas that are not affected } \\
\text { by the tumor }\end{array}$ & $\begin{array}{l}\text { According to conventional dental } \\
\text { standards }\end{array}$ \\
\hline Prosthetic treatment & $\begin{array}{l}\text { Transurgical palatal obturator for maxillary surgeries; }{ }^{14} \\
\text { perform pre-prosthetic planing }\end{array}$ & $\begin{array}{l}\text { Maxillofacial prosthetic rehabilitation } \\
\text { via a definitive palatal obturator } \\
\text { adapted mandibular or maxillofacial } \\
\text { prosthesis }{ }^{17,18}\end{array}$ \\
\hline
\end{tabular}

aTooth brushing frequency: upon waking, before bed, and after all meals

Subsequently, these patients can be treated according to conventional dental standards; at follow-up appointments, it's important to pay attention to recurrent or new lesions that may develop in the oral cavity ${ }^{15,16}$ (Table 1). In the context of surgeries involving the jaws, it is crucial to highlight the importance of definitive rehabilitation, to allow their reintegration into society and their aesthetic standards. ${ }^{17,18}$ In this sense, the maxillofacial prosthetics palatal obturator works as an aid in supporting the tissue, improving healing, reducing contamination and the possibility of infections; it also reduces the need for a nasoenteral tube, since it allows the patient to swallow efficiently and also an early initiation of oral feeding. ${ }^{19}$ Maxillary and mandibular adapted prostheses are essential to rehabilitating function and aesthetics. Its manufacture must follow the basic principles of dental prosthesis, which occasionally can be modified to adapt to an unusual anatomy ${ }^{20}$ and intraosseous implants may be required for better retention and stability. ${ }^{21}$ The maxillofacial prosthesis is constituted of synthetic material and molded according to specific surgical defects, allowing the repair of deformities, contributing to the aesthetic and functional rehabilitation, and the consequent return of patients' self-esteem. ${ }^{17} \mathrm{An}$ example can be observed in Figure 1.

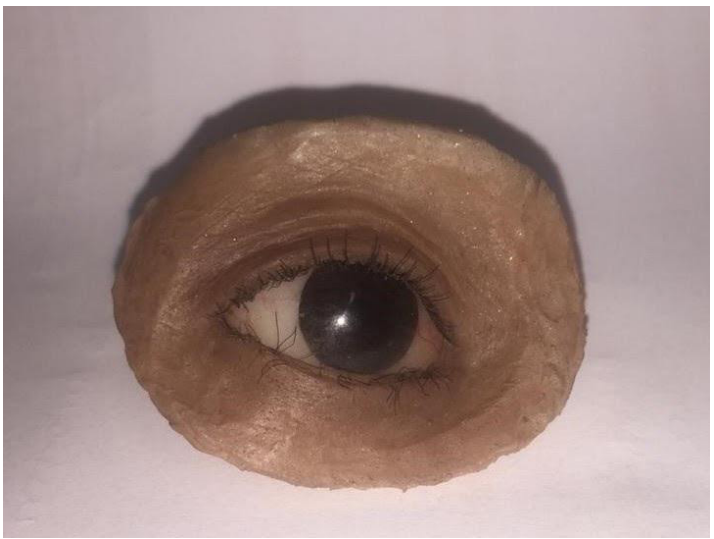

Figure I Front view of a silicone eyelid prosthesis. 


\section{Dental care for patients undergoing head and neck radiotherapy}

$\mathrm{RT}$ is a treatment modality for malignant tumors whose therapeutic agent is ionizing radiation, responsible for promoting ionization in the environment where it occurs. Most patients undergoing RT receive a total dose of 50-70Gy as a curative dose. These doses are divided into a period of 5-7 weeks, once a day, 5 days a week, with a daily dose of approximately $2 \mathrm{~Gy} .{ }^{22}$ Dental assessment before RT in patients with $\mathrm{H} \& \mathrm{~N}$ cancer aims to minimize oral manifestations. ${ }^{23}$ The patient must undergo a physical examination, including periodontal analysis through probing and a radiographic examination. ${ }^{23}$ Dental planning must be programmed in a joint analysis with the estimated radiation dose for each oral site (Table 2). ${ }^{23}$

Table 2 Dental care for patients undergoing head and neck radiotherapy

\begin{tabular}{|c|c|c|c|}
\hline & $\begin{array}{l}\text { Pre-RT management for intraoral fields } \\
\text { to be irradiated with doses }>40 \mathrm{~Gy}\end{array}$ & Management during RT & $\begin{array}{l}\text { Post-RT management for intraoral } \\
\text { fields irradiated with doses }>40 \mathrm{~Gy}\end{array}$ \\
\hline $\begin{array}{l}\text { Oral hygiene } \\
\text { instruction }\end{array}$ & $\begin{array}{l}\text { Tooth brushing }{ }^{\mathrm{a}} \text { with a soft brush and fluoride } \\
\text { toothpaste }^{79}\end{array}$ & $\begin{array}{l}\text { Tooth brushing }{ }^{\mathrm{a}} \text { with an extra soft } \\
\text { brush and fluoride toothpaste; } \\
0.12 \% \text { chlorhexidine-based } \\
\text { mouthwashes }^{40}\end{array}$ & $\begin{array}{l}\text { Tooth brushing }{ }^{a} \text { with a soft brush and } \\
\text { fluoride toothpaste; } ;^{79} \text { use a tray with } 2 \% \\
\text { neutral fluoride, } 5 \text { minutes, every day before } \\
\text { sleep }^{37,38}\end{array}$ \\
\hline $\begin{array}{l}\text { Oral } \\
\text { environment } \\
\text { adequacy }\end{array}$ & $\begin{array}{l}\text { Treatment of mucosal infections and } \\
\text { elimination of trauma source }\end{array}$ & $\begin{array}{l}\text { Treatment of acute oral toxicities: } \\
\text { dysgeusia, oral mucositis, bacterial, } \\
\text { viral, and fungal infections, } \\
\text { xerostomia, and pain }{ }^{24}\end{array}$ & $\begin{array}{l}\text { Treatment of chronic oral toxicities: } \\
\text { fibrosis of the oral mucosa, radiation caries, } \\
\text { functional sequelae, xerostomia, ORN, and } \\
\text { trismus; }{ }^{24} \text { diagnosis of recurrent lesions }\end{array}$ \\
\hline $\begin{array}{l}\text { Periodontal } \\
\text { treatment }\end{array}$ & $\begin{array}{l}\text { Dental cleaning and scraping according to } \\
\text { conventional dental standards are indicated } \\
\text { to teeth with periodontal pockets measuring } \\
4-5 \mathrm{~mm}^{86}\end{array}$ & Only emergency procedures ${ }^{16,87}$ & $\begin{array}{l}\text { According to conventional dental standards, } \\
\text { avoiding bone manipulation, to reduce ORN } \\
\text { risk }^{88}\end{array}$ \\
\hline $\begin{array}{l}\text { Restorative } \\
\text { treatment }\end{array}$ & $\begin{array}{l}\text { Restoration of minor caries lesions, according } \\
\text { to conventional dental standards; }{ }^{16} \text { adjusting } \\
\text { or replacing pre-existing restorations }\end{array}$ & Only emergency procedures ${ }^{16,87}$ & $\begin{array}{l}\text { Preferably with glass ionomer cement } \\
\text { due to fluoride release; radiation-induced } \\
\text { changes in enamel and dentine may } \\
\text { compromise bonding of adhesive materials, } \\
\text { therefore, composite restorations often } \\
\text { experience loss of retention and caries } \\
\text { recurrence }^{87}\end{array}$ \\
\hline $\begin{array}{l}\text { Endodontic } \\
\text { treatment }\end{array}$ & $\begin{array}{l}\text { Indicated to teeth with periapical radiolucent } \\
\text { lesion without symptoms (with or without } \\
\text { previous endodontic treatment); pulp without } \\
\text { vitality with or without symptoms and } \\
\text { without periapical radiolucent lesion }{ }^{86}\end{array}$ & Only emergency procedures ${ }^{16,87}$ & $\begin{array}{l}\text { Teeth with conventional indications and root } \\
\text { debris for burial with antibiotic prophylaxis } \\
\text { during the endodontic treatment; the } \\
\text { instrumentation, irrigation, drying, and } \\
\text { medication of the canal must be monitored } \\
\text { accurately; avoiding caustic substances to } \\
\text { avoid inflammation; do not leave the tooth } \\
\text { open "to drain"89 }\end{array}$ \\
\hline $\begin{array}{l}\text { Surgery } \\
\text { treatment } \\
\text { (teeth } \\
\text { or roots } \\
\text { extraction, } \\
\text { intraosseous } \\
\text { lesions, } \\
\text { periodontal } \\
\text { surgery, } \\
\text { implants) }\end{array}$ & $\begin{array}{l}\text { Extraction }{ }^{c} \text { of dental elements with deep } \\
\text { caries in which excavation can lead to pulp } \\
\text { exposure, extensive periapical lesion seen } \\
\text { on radiographs combined with periodontal } \\
\text { disease in symptomatic teeth, teeth with } \\
\text { periodontal pockets } \geq 6 \mathrm{~mm} \text {, teeth with } \\
\text { gingival recession } \geq 6 \mathrm{~mm} \text {, teeth or roots } \\
\text { partially impacted or with radiographic } \\
\text { abnormalities such as periapical lesions and } \\
\text { teeth with internal or external resorption; }{ }^{23} \\
\text { removal of intraosseous lesions. } \\
\text { se Periodontal } \\
\text { surgery should only be performed if } \\
\text { there is enough time to complete the } \\
\text { reabilotation procedure; implnats should } \\
\text { only be performed if there is enough time to } \\
\text { complete osseointegration }\end{array}$ & $\begin{array}{l}\text { Not indicated; if necessary, they } \\
\text { should be performed with minimal } \\
\text { trauma by a specialist }{ }^{87}\end{array}$ & $\begin{array}{l}\text { Should be avoided due to the risk of ORN; } \\
\text { given the absolute indication for surgical } \\
\text { procedures with bone manipulation, the } \\
\text { minimally invasive surgical technique should } \\
\text { be employed, that is, avoiding osteotomy } \\
\text { and seeking primary synthesis, as well as } \\
\text { assessing the need for antibiotic prophylaxis; } \\
\text { mouthwash with chlorhexidine should be } \\
\text { used preoperatively and postoperatively } \\
\text { until the healing of the extraction wound is } \\
\text { observed } 79,90\end{array}$ \\
\hline $\begin{array}{l}\text { Prosthetic } \\
\text { treatment }\end{array}$ & $\begin{array}{l}\text { Removable prostheses with jagged or rough } \\
\text { edges that may implicate trauma should be } \\
\text { adjusted }^{90}\end{array}$ & $\begin{array}{l}\text { Not indicated, and the patient } \\
\text { should only use removable } \\
\text { prostheses, for food or social } \\
\text { situations }^{88}\end{array}$ & $\begin{array}{l}\text { Generally, removable prostheses should be } \\
\text { avoided, due to trauma; they can be used } \\
\text { only for aesthetics or function }{ }^{87}\end{array}$ \\
\hline
\end{tabular}

$\mathrm{RT}$, radiotherapy; ORN, osteoradionecrosis

aTooth brushing frequency: upon waking, before bed, and after all meals;

bShould only be performed if there is enough time to complete the procedure and for the apex lesion to regress until the beginning of the RT, otherwise extraction should be recommended; 86

${ }^{c}$ There must be $2 \mathrm{I}$ days between the extraction and the beginning of the RT, to guarantee the initial healing of the oral tissues. ${ }^{23}$ 
During RT, routine dental treatment is not indicated; only evaluation and resolution of dental emergencies should be performed (Table 2). The dental surgeon must diagnose and treat the RT acute oral toxicities ${ }^{24}\left(\mathrm{OM}^{25-27}\right.$, dysgeusia, ${ }^{12,22,28,29}$ infections, pain, and xerostomia) (Table 3), that implicate an inability to eat, speak, clean, increased costs with hospitalization, and reduced quality of life. ${ }^{30-33}$

Table 3 Management of acute and chronic oral toxicities from antineoplastic therapy

\begin{tabular}{|c|c|c|c|c|c|}
\hline & CT & HSCT & RT & Management & Observations \\
\hline \multicolumn{6}{|c|}{ Acute oral toxicities } \\
\hline aGVDH & No & Yes & No & $\begin{array}{l}\text { Mouthwashes with corticosteroids } \\
\text { (dexamethasone }(0.1 \mathrm{mg} / \mathrm{mL}) \text { and } \\
\text { clobetasol }(0.5 \mathrm{mg} / \mathrm{mL}) \text { can be used }\end{array}$ & It is not a usual manifestation \\
\hline $\begin{array}{l}\text { Bacterial, viral, } \\
\text { and fungal } \\
\text { infections }\end{array}$ & Yes & Yes & Yes & $\begin{array}{l}\text { Prescription of specific medications } \\
\text { according to the responsible pathogen }\end{array}$ & $\begin{array}{l}\text { Infections usually present atypical clinical features in } \\
\text { immunosuppressed patients (CT and HSCT); in the cases } \\
\text { of fungal infections, treatment with nystatin solution }{ }^{12,28} \text { or } \\
\text { fluconazole }{ }^{79,92} \text { are recommended }\end{array}$ \\
\hline Dysgeusia & Yes & No & Yes & $\begin{array}{l}\text { Nutritional care, constant water intake, } \\
\text { and use of salivary substitutes are } \\
\text { recommended }\end{array}$ & $\begin{array}{l}\text { In a recent study, the use of zinc-L-carnosine demonstrated } \\
\text { encouraging results in the treatment of dysgeusia in these } \\
\text { patients94 }\end{array}$ \\
\hline Oral mucositis & Yes & Yes & Yes & $\begin{array}{l}\text { Application of low-power laser }(660 \mathrm{~nm} \text {, } \\
\left.8 \mathrm{~J} / \mathrm{cm}^{2}\right) \text { from the appearance of oral } \\
\text { mucositis until healing }\end{array}$ & $\begin{array}{l}\text { Add dexamethasone mouthwash (mildest OM by mTOR } \\
\text { inhibitors; }{ }^{54,55} \text { and OM by tyrosine kinase inhibitors } \\
\text { EGFR/ HERI, Pan-HER or EGFR-inhibiting monoclonal } \\
\text { antibody }{ }^{55} \text { ); clobetasol gel or cream, or intralesional } \\
\text { triamcinolone injection (severe OM by mTOR inhibitors); }{ }^{55} \\
\text { dose adjustment or treatment interruption, and high-dose } \\
\text { systemic corticosteroids, should be considered in line with } \\
\text { the oncologist (unresponsive cases) }\end{array}$ \\
\hline Pain & Yes & Yes & Yes & \multicolumn{2}{|c|}{$\begin{array}{l}\text { Opioids prescription; }{ }^{53} \text { associated with OM, should be managed with topical } 0.2 \% \text { morphine } \\
\text { prescription }^{96}\end{array}$} \\
\hline Neurotoxicity & Yes & No & No & \multicolumn{2}{|c|}{$\begin{array}{l}\text { Prescription of opioids or, if they don't work, anticonvulsants, antidepressants, corticosteroids, and } \\
\text { anesthetics, as well as nutritional supplementation with alpha-lipoic acid, vitamin E, erythropoietin, and } \\
\text { acetyl-L-carnitine }{ }^{53}\end{array}$} \\
\hline Xerostomia & Yes & Yes & Yes & \multicolumn{2}{|c|}{ Use of salivary stimulants (mechanical or gustatory), salivary substitutes, or systemic agents ${ }^{12,24}$} \\
\hline \multicolumn{6}{|c|}{ Chronic oral toxicities } \\
\hline cGVDH & No & Yes & No & $\begin{array}{l}\text { Prescription of high-potency topical cort } \\
\text { artificial saliva, oral rinses, sugar-free canc }\end{array}$ & $\begin{array}{l}\text { teroids, calcineurin inhibitors, and analgesics; } ;^{97} \text { use of } \\
\text { sialogougues }{ }^{71}\end{array}$ \\
\hline Pain & No & Yes & Yes & Opioids prescription ${ }^{53}$ & \\
\hline $\begin{array}{l}\text { Radiation } \\
\text { dental caries }\end{array}$ & No & No & Yes & \multicolumn{2}{|c|}{$\begin{array}{l}\text { The removal of carious tissue is recommended through manual curettes and the use of cariostatic } \\
\text { substances, with the subsequent restoration of the elements with resin glass ionomer }{ }^{35,104}\end{array}$} \\
\hline $\begin{array}{l}\text { Second } \\
\text { primary } \\
\text { tumor }\end{array}$ & Yes & Yes & Yes & \multicolumn{2}{|c|}{ Perform biopsy to diagnose and refer the patient to the oncologist for new cancer treatment ${ }^{71}$} \\
\hline Trismus & No & Yes & Yes & \multicolumn{2}{|c|}{$\begin{array}{l}\text { A strict regimen of oral exercises associated with physiotherapy is recommended to minimize this } \\
\text { complication }{ }^{85}\end{array}$} \\
\hline Xerostomia & Yes & Yes & Yes & \multicolumn{2}{|c|}{ Use of salivary stimulants (mechanical or gustatory), salivary substitutes, or systemic agents 12,24} \\
\hline
\end{tabular}

CT, chemotherapy; HSCT, hematopoietic stem cell transplantation; RT, radiotherapy; aGVDH, acute graft versus host disease; cGVDH, chronic graft versus host disease; ORN, osteoradionecrosis

After completion of RT, the patient must be closely monitored to identify and manage possible complications. At first, dental followup appointments should be monthly, changing to quarterly after most acute toxicities are controlled. The dentist's actions must be preventive, to promote oral health, and procedures that involve bone manipulation (such as extractions and dental implants) should be avoided due to the risk of osteoradionecrosis $(\mathrm{ORN})^{24}$ (Table 2). Moreover, the chronic oral toxicities, which are a limited opening of the mouth (trismus) associated with mucosal fibrosis, ${ }^{27}$ pain in the mucous membranes, second primary tumors, xerostomia, ${ }^{12,32,34}$ radiation-induced dental caries $^{35-38}$ and ORN, ${ }^{30,32,39-41}$ should be diagnosed and treated (Table 3). Cases of radiation-induced dental caries and ORN are shown in Figures 2 and 3, respectively. Considering that RT is a local treatment, a dentist should, as previously stated in the surgery section, pay attention to possible recurrence, identifying, and forwarding to the oncologist as soon as possible for better management. 


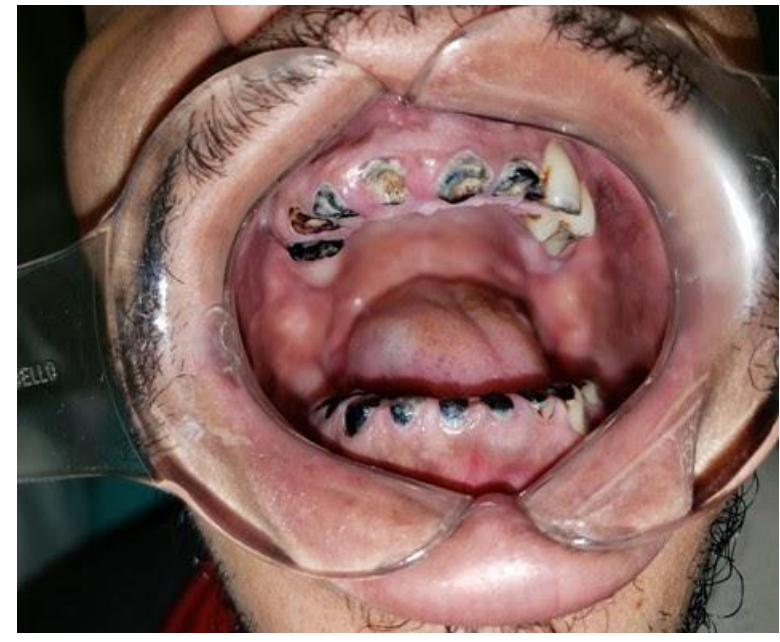

Figure $\mathbf{2}$ Intraoral aspect of a patient with generalized dental involvement due to radiation-induced dental caries after RT treatment.

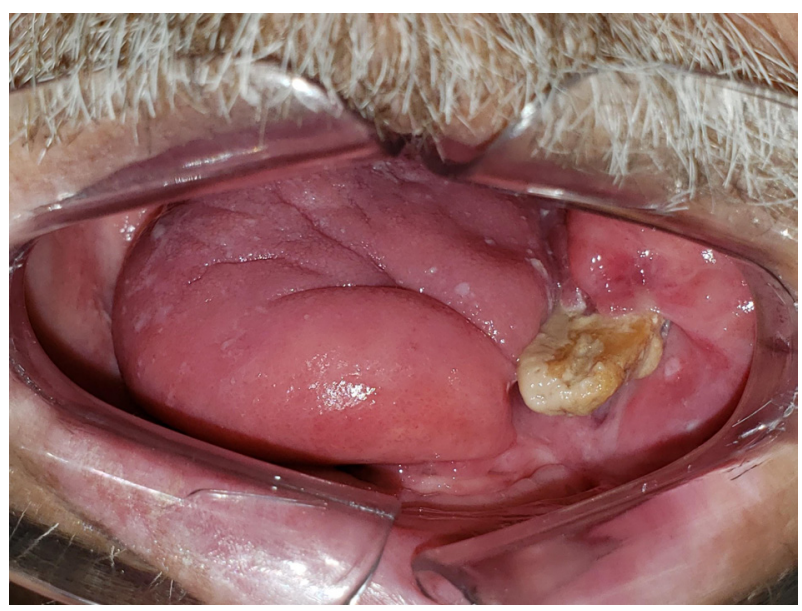

Figure 3 Intraoral photograph of jaw ORN.

\section{Dental care for patients undergoing chemotherapy}

$\mathrm{CT}$ is the systemic treatment that uses antineoplastic drugs in regular intervals, according to the therapeutic regimen. ${ }^{42}$ It can be used in association with other treatment modalities, in adjuvant (to avoid tumor spread) or in neoadjuvant (to stimulate the reduction of the tumor), thus optimizing surgery or RT. ${ }^{43}$ The therapeutic scheme of choice relies on histopathological and molecular diagnosis, clinical condition, functional capacity, and patient preference; monotherapy or polychemotherapy can be used..$^{44,45}$

Dental planning before CT may be more conservative when compared to the one for RT or HSCT. The prior dental evaluation must consist of an oral hygiene instruction, elimination of caries, periodontal disease, endodontic infections, and other possible foci of infection in the oral cavity that may be exacerbated during the neutropenic stage expected for these patients (Table 4). ${ }^{46}$

Given CT is a systemic therapy, during treatment, especially in the period of immunosuppression, it may cause changes in the oral mucosa that may lead to a direct impact on the patient's quality of life, occasionally leading to treatment interruption. ${ }^{47}$ Therefore, during CT, dental management should consist of emergency procedures - always considering laboratory exams (Table 4)- and the management of acute oral toxicities (OM, dysgeusia, xerostomia, bacterial, viral, and fungal infections ${ }^{40,47-50}$ and neurotoxicity ${ }^{27,51)}$ (Table 3 ).

It is important to note that some CT drugs are more toxic to the tissues, being frequently associated with $\mathrm{OM}$, such as methotrexate, 5-fluorouracil, cyclophosphamides, cisplatin, and purine analogs such as cytarabine. ${ }^{52,53}$ Regarding OM caused by mTOR inhibitors, ${ }^{54,55}$ tyrosine kinase inhibitors EGFR/HER1, Pan-HER, or EGFR-inhibiting monoclonal antibodies, ${ }^{55}$ they have distinct clinical presentations and specific management (Table 3).

Considering that acute effects related to CT tend to cease soon after the organism's recovery, the patient undergoing CT does not need long-term post-treatment care that would differ from those dispensed in routine annual dental consultations (Table 4). Despite that, the dentist should pay attention to possible metastatic lesions that may manifest in the oral cavity. ${ }^{56}$ These manifestations are rare in this area, indicate advanced disease progression, ${ }^{57,58}$ and imply a poor prognosis when it comes to survival..$^{57,59}$ The identification and early management of these can significantly impact the management (thought palliative treatment-seeking maintenance of oral function and management of pain) and patient's quality of life. ${ }^{57,58}$

Table 4 Dental care for patients undergoing CT

\begin{tabular}{|c|c|c|c|}
\hline & Pre-CT management & Management during CT & Post-CT management \\
\hline $\begin{array}{l}\text { Oral hygiene } \\
\text { instruction }\end{array}$ & $\begin{array}{l}\text { Tooth brushing }{ }^{\mathrm{a}} \text { with a soft brush and } \\
\text { fluoride toothpaste }^{79}\end{array}$ & $\begin{array}{l}\text { Tooth brushing }{ }^{\text {a }} \text { with an extra soft } \\
\text { brush and fluoride toothpaste } ;^{79} 0.12 \% \\
\text { chlorhexidine-based mouthwashes }{ }^{40}\end{array}$ & $\begin{array}{l}\text { Tooth brushing }{ }^{\mathrm{a}} \text { with a soft brush and } \\
\text { fluoride toothpaste } \mathrm{f}^{51,79}\end{array}$ \\
\hline $\begin{array}{l}\text { Oral environment } \\
\text { adequacy }\end{array}$ & $\begin{array}{l}\text { Treatment of mucosal infections }{ }^{51,105} \\
\text { and elimination of any trauma source, }{ }^{46} \\
\text { such as orthodontic device }\end{array}$ & $\begin{array}{l}\text { Treatment of acute oral toxicities: } \\
\text { oral mucositis, dysgeusia, xerostomia, } \\
\text { bacterial, viral, and fungal infections }{ }^{40,47-50} \\
\text { and neurotoxicity }{ }^{27,51}\end{array}$ & $\begin{array}{l}\text { Diagnosis of recurrent and metastatic } \\
\text { lesions; }{ }^{56-59} \text { check for infections (viral } \\
\text { and fungal) }{ }^{51}\end{array}$ \\
\hline $\begin{array}{l}\text { Periodontal } \\
\text { treatment }\end{array}$ & $\begin{array}{l}\text { Dental cleaning and scraping according } \\
\text { to conventional dental standards } s^{46,51}\end{array}$ & $\begin{array}{l}\text { Necessary dental care, always } \\
\text { considering laboratory exams }\end{array}$ & $\begin{array}{l}\text { Need for routine systematic oral } \\
\text { hygiene }{ }^{107}\end{array}$ \\
\hline $\begin{array}{l}\text { Restorative } \\
\text { treatment }\end{array}$ & $\begin{array}{l}\text { Restoration of minor caries lesions; } \\
\text { adjusting or replacing pre-existing } \\
\text { restorations }{ }^{40,46,51,105} \text { according to } \\
\text { conventional dental standards }\end{array}$ & $\begin{array}{l}\text { Necessary dental care, always } \\
\text { considering laboratory exams }\end{array}$ & $\begin{array}{l}\text { According to conventional dental } \\
\text { standards }\end{array}$ \\
\hline
\end{tabular}


Table Continued...

\begin{tabular}{|c|c|c|c|}
\hline & Pre-CT management & Management during CT & Post-CT management \\
\hline $\begin{array}{l}\text { Endodontic } \\
\text { treatment }\end{array}$ & $\begin{array}{l}\text { Endodontic treatment of severe caries } \\
\text { with pulp involvement, dental abscess, } \\
\text { and apical periodontitis (symptomatic } \\
\text { lesions and lesions } \geq 5 \mathrm{~mm})^{40,46,51,105} \text {, } \\
\text { if the patient's systemic conditions } \\
\text { allow }\end{array}$ & $\begin{array}{l}\text { Necessary dental care, always } \\
\text { considering laboratory exams }\end{array}$ & $\begin{array}{l}\text { According to conventional dental } \\
\text { standards }^{107}\end{array}$ \\
\hline $\begin{array}{l}\text { Surgery treatment } \\
\text { (teeth or roots } \\
\text { extraction, } \\
\text { intraosseous lesions, } \\
\text { periodontal surgery, } \\
\text { implants) }\end{array}$ & $\begin{array}{l}\text { Extraction of teeth with apical } \\
\text { periodontitis, pocket depth }(\geq 6 \mathrm{~mm}) \text {, } \\
\text { furcation I, II or III, partially impacted } \\
\text { teeth, root debris, intraosseous lesions, } \\
\text { radiographic abnormalities such as } \\
\text { root resorption and mobile primary } \\
\text { teeth with }>50 \% \text { root resorption }{ }^{46} \text { if } \\
\text { the patient's systemic conditions allow }\end{array}$ & $\begin{array}{l}\text { Necessary dental care, always } \\
\text { considering laboratory exams }\end{array}$ & $\begin{array}{l}\text { According to conventional dental } \\
\text { standards, }{ }^{107} \text { as long as the blood } \\
\text { count and biochemical tests } \\
\text { allow, except }{ }^{d} \text { for patients using } \\
\text { bevacizumab }{ }^{108}\end{array}$ \\
\hline Prosthetic treatment & $\begin{array}{l}\text { Denture fitting should be checked, } \\
\text { with readjustment or removal of those } \\
\text { prostheses that cause trauma }\end{array}$ & $\begin{array}{l}\text { Not indicated, and the patient should } \\
\text { only use removable prostheses, for food } \\
\text { or social situations }\end{array}$ & $\begin{array}{l}\text { According to conventional dental } \\
\text { standards, }{ }^{105} \text { but the best time to } \\
\text { perform the procedure should be } \\
\text { discussed and agreed upon with the } \\
\text { responsible oncologist }^{51}\end{array}$ \\
\hline
\end{tabular}

aToothbrushing frequency: upon waking, before bed, and after all meals;

bShould only be performed if there is enough time to complete the procedure and for the apex lesion to regress until the beginning of the chemotherapy, otherwise extraction should be recommended; 51

'At least 2 weeks before chemotherapy starts, so that there is time for healing; ${ }^{51}$

dPatients using bevacizumab have difficulty in healing, therefore, in these cases, a 28 days interval after drug interruption should be given before performing surgery and further 28 days to restart the drug. ${ }^{108}$

\section{Dental care for patients undergoing hematopoietic stem cell transplantation}

HSCT is the therapeutic modality for hematological diseases' treatment, whether benign or malignant, hereditary or acquired among them are leukemias, lymphomas, and multiple myeloma. ${ }^{60}$ It consists of providing the patient with hematopoietic stem cells that will be lodged in the bone marrow, to re-establish their function. ${ }^{61}$ HSCT can be autogenic, allogeneic, or syngeneic and the progenitor

Table 5 Dental care for patients undergoing HSCT cells may come from bone marrow, peripheral blood, or umbilical cord. ${ }^{62}$

Dental care before HSCT should be performed on all patients to minimize the complications during treatment, ${ }^{46}$ according to Table 5. During the HSCT, acute oral toxicities ${ }^{62}$ (infections, OM, ${ }^{63,64}$ xerostomia ${ }^{63}$ and acute graft versus host disease (aGVHD) $)^{65,66}$ must be controlled (Table 3) and emergency procedures performed, ${ }^{51}$ always considering laboratory exams (Table 5). Figure 4 illustrates one of the possible clinical presentations of aGVHD.

\begin{tabular}{|c|c|c|c|}
\hline & Pre-HSCT management & Management during HSCT & Post-HSCT management \\
\hline $\begin{array}{l}\text { Oral hygiene } \\
\text { instruction }\end{array}$ & $\begin{array}{l}\text { Tooth brushing }{ }^{\mathrm{a}} \text { with a soft brush } \\
\text { and fluoride toothpaste }\end{array}$ & $\begin{array}{l}\text { Tooth brushing }{ }^{\mathrm{a}} \text { with } \\
\text { an extra soft brush and } \\
\text { fluoride toothpaste }{ }^{79} \\
0.12 \% \text { chlorhexidine-based } \\
\text { mouthwashes }{ }^{40}\end{array}$ & $\begin{array}{l}\text { Tooth brushing }{ }^{\text {a }} \text { with a soft brush and } \\
\text { fluoride toothpaste }\end{array}$ \\
\hline $\begin{array}{l}\text { Oral environment } \\
\text { adequacy }\end{array}$ & $\begin{array}{l}\text { Treatment of mucosal infections } \\
\text { and elimination of any trauma } \\
\text { source }^{46}\end{array}$ & $\begin{array}{l}\text { Treatment of acute oral } \\
\text { toxicities: infections, oral } \\
\text { mucositis, xerostomia, and acute } \\
\text { graft versus host disease }{ }^{62}\end{array}$ & $\begin{array}{l}\text { Treatment of chronic oral toxicities: } \\
\text { xerostomia, }{ }^{51,63} \text { chronic graft versus host } \\
\text { disease; }{ }^{11,65} \text { Diagnosis of second primary } \\
\text { tumors, }{ }^{70} \text { recurrence and metastasis lesions }\end{array}$ \\
\hline Periodontal treatment & $\begin{array}{l}\text { Dental scaling according to } \\
\text { conventional dental standards }{ }^{46,51}\end{array}$ & $\begin{array}{l}\text { Only emergency procedures, } \\
\text { always taking laboratory tests } \\
\text { into account }^{51}\end{array}$ & $\begin{array}{l}\text { Dental disease should be considered } \\
\text { a source of infection and therefore } \\
\text { should be managed routinely, avoiding } \\
\text { invasive treatment. Removal of dental } \\
\text { plaque deposits using an ultrasonic scaler } \\
\text { should be minimized if the patient is } \\
\text { immunosuppressed }^{51}\end{array}$ \\
\hline
\end{tabular}


Table Continued..

\section{Pre-HSCT management}

Restoration of minor caries lesions; adjusting or replacing pre-existing restorations $\mathrm{s}^{40,46,51,105}$ according to conventional dental standards

\section{Endodontic treatment of severe} caries, pulp involvement, dental abscess, and apical periodontitis

\section{Endodontic treatment}

Surgery treatment (teeth or roots extraction, intraosseous lesions, periodontal surgery, implants)

\section{Prosthetic treatment}

(symptomatic lesions and lesions $<6$ $\mathrm{mm})^{40,46,51,105}$, if the patient's systemic conditions allow ${ }^{b}$

Extraction of teeth with apical periodontitis, pocket depth ( $\geq 6 \mathrm{~mm})$, furcation I, II or III, partially impacted teeth, root debris, intraosseous lesions, radiographic abnormalities such as root resorption and mobile primary teeth with $>50 \%$ root resorption ${ }^{46}$ if the patient's systemic conditions allow ${ }^{c}$

Denture fitting should be checked, with readjustment or removal of those prostheses that cause trauma ${ }^{51,107}$

\section{Management during HSCT Post-HSCT management}

Only emergency procedures, always taking laboratory tests into account ${ }^{51}$

Only emergency procedures, always taking laboratory tests into account ${ }^{51}$
Dental disease should be considered a source of infection and therefore should be managed routinely, avoiding invasive treatment. Procedures that generate aerosols that may lead to aspiration, should be minimized if the patient is immunosuppressed ${ }^{51}$

Dental disease should be considered as a source of infection and therefore should be managed routinely ${ }^{51}$
Only emergency procedures, always taking laboratory tests into account ${ }^{51}$
Dental disease should be considered as a source of infection and therefore should be managed routinely ${ }^{51}$
Not indicated, and the patient should only use removable prostheses, for food or social situations ${ }^{51}$

\section{According to conventional dental} standards ${ }^{105}$, but the best time to perform the procedure should be discussed and agreed upon with the responsible oncologist $^{51}$

\section{${ }^{a}$ Toothbrushing frequency: upon waking, before bed, and after all meals;}

bShould only be performed if there is enough time to complete the procedure and for the apex lesion to regress until the beginning of chemotherapy, otherwise extraction should be recommended; ${ }^{1}$

'At least 2 weeks before chemotherapy starts, so that there is time for healing. ${ }^{5}$

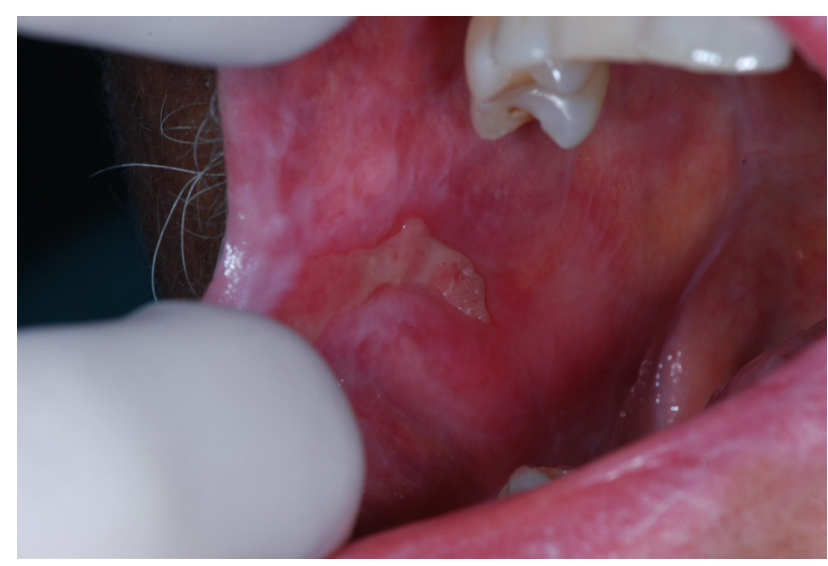

Figure 4 Oral manifestation of aGVHD.

The patient should be maintained in control via a semiannual consultation program or following specific needs after the immediate HSCT and annual control in late HSCT stages. In these consultations, the dentist must plan dental treatments according to Table 5 and diagnose and/or treat chronic toxicities such as xerostomia, ${ }^{63}$ trismus, chronic graft versus host disease (cGVHD), ${ }^{65,67}$ and second primary tumor $^{66,68-70}$ (Table 3). A case of cGVHD is represented in Figure
5. As previously reported in the CT section, the dentist should also pay attention, in the follow-up appointments, to oral lesions that could indicate metastasis from other tumors manifesting in the oral cavity. Patients with Fanconi anemia undergoing HSCT should be scheduled for control visits every 6 months, due to the increased risk of developing squamous cell carcinomas in the oral cavity. ${ }^{71}$

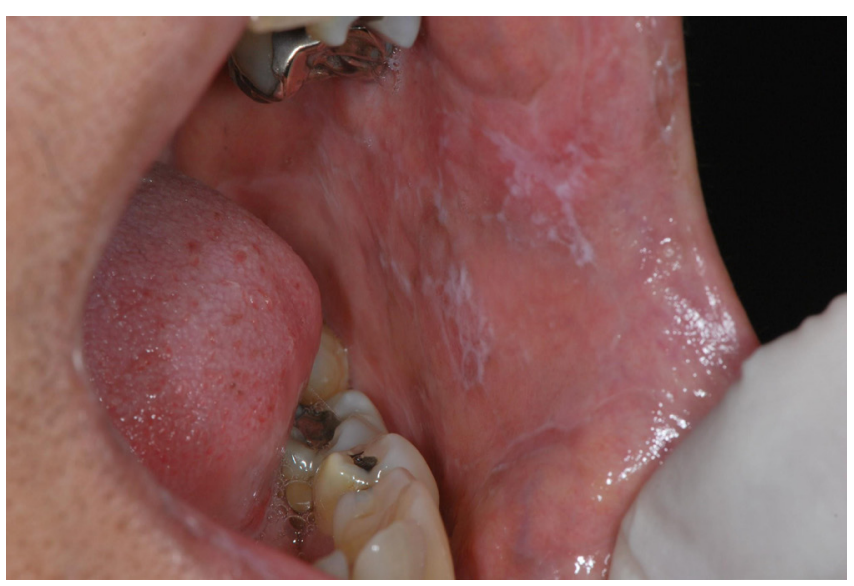

Figure 5 Oral manifestation of cGVHD. 


\section{Dental care for patients in the use of antiresorptive medications}

In the oncological context, it is necessary to consider patients that use bisphosphonates (BPs) intravenous (IV) or orally or denosumab due to the association of these drugs with medication-related osteonecrosis of the jaws (MRONJ). Despite the low incidence, MRONJ causes an abrupt drop in patient's quality of life. ${ }^{72}$ In this same context, it is important to also consider the use of antiangiogenic drugs, as this association increases the risks of developing MRONJ. ${ }^{73}$

BPs are synthetic pyrophosphate-like drugs, which bind tightly to hydroxyapatite and reduce metabolism and bone remodeling. They are medications with a long half-life and thus remain in the bone tissue for more than 10 years after treatment interruption..$^{73}$ The main BPs associated with MRONJ cases are zoledronate, pamidronate, IV ibandronate, alendronate, oral ibandronate, risedronate, and clodronate. ${ }^{74}$ These drugs are prescribed for patients at risk/evidence of bone metastasis, or for the treatment of multiple myeloma, Paget's disease, and disorders of calcium metabolism. ${ }^{75-77}$

Denosumab is a monoclonal antibody that binds to the receptorligand responsible for the activation of the nuclear factor kappa B ligand (RANK-L), thus blocking the maturation, function, and survival of osteoclasts. It is also prescribed for patients presenting osteoporosis or risk/evidence of bone metastasis. Unlike BPs, this medicine has a half-life of 25 to 32 days. $^{73}$

The dentist is responsible for investigating the use of these drugs during anamnesis, both in cancer patients and in the general population, before defining the dental treatment plan. The ideal is that before starting the use of antiresorptive medications, patients should be evaluated and prepared by the dentist to minimize the subsequent need for invasive treatment, ${ }^{72}$ and the patient should be guided and managed similarly to those subject to RT for H\&N tumors ${ }^{77}$ (Table 2).

Patients using antiresorptive medications should be scheduled for a control visit every 6 months. Dental management is also similar to that employed after RT (Table 2), to maintain the status of adequate oral hygiene and perform an early diagnosis of MRONJ and eventual metastatic manifestations in the oral cavity. The MRONJ management is still controversial and can include non-surgical procedures, such as pain and infection control (oral hygiene care, periodontal disease management, chlorhexidine gluconate $0.12 \%$ mouthwash, antibiotic therapy, and systemic corticosteroid therapy) and surgical treatment when necessary. ${ }^{72}$

After the start of therapy, given the absolute indication for surgical procedures with bone manipulation, the minimally invasive surgical technique should be employed, that is, avoiding osteotomy and seeking primary synthesis, as well as assessing the need for antibiotic prophylaxis; mouthwash with $0,12 \%$ chlorhexidine should be used preoperatively and postoperatively until healing; suspension of therapy according to each case should be assessed. ${ }^{73,75,77,78}$ For patients who have had oral BP for less than 4 years and do not have associated risk factors, changes in surgical planning are not necessary. On the other hand, for patients using oral BP associated with corticosteroids and antiangiogenics, also for less than 4 years, it is suggested that the BP should be interrupted for 2 months before extractions until full bone healing. Likewise, it should be discontinued in patients treated for more than 4 years, that is, 2 months before the procedure until full bone healing. The maneuvers for suspending and resuming drug use must be agreed with the oncologist responsible for conducting the patient's treatment. ${ }^{77}$
Regarding the interruption of IV BPs, data in the literature is still scarce, and there is no established guideline. However, in cases of MRONJ, the oncologist may consider interrupting antiresorptive therapy until soft tissue is fully healed over the jawbones, depending on the status of the disease. Regarding denosumab, it was observed that its antiresorptive effects dissipate approximately within 6 months after discontinuing the drug, however, there are no studies to support or refute this strategy for prevention or treatment of MRONJ, making further studies necessary. ${ }^{77}$

It is also important to consider the use of antiangiogenics, prescribed mainly for cancer patients for inhibiting several mechanisms involved in tumor neoangiogenesis. In this group of drugs, bevacizumab (inhibitor of vascular endothelial growth factor), sunitinib (tyrosine kinase inhibitor), and everolimus (inhibitors of the target protein of rapamycin in mammals) stand out. These medicines do not tend to accumulate in the bone and their half-life range from 30 hours for everolimus to 20 days for bevacizumab, varying according to the medication..$^{73}$ It is important to note that the benefits versus risks of discontinuing therapies must be calculated jointly with the oncologist and the patient, ${ }^{78}$ according to their systemic conditions.

\section{Conclusion}

The consulted articles were unanimous regarding the need for dental care in pre, trans, and post-treatment cancer patients, showing the importance of including specialized dental surgeons in the oncology care team. In this way, the dentist must act in the direction of prevention, early diagnosis, and treatment of oral toxicities. The dentist is responsible for minimizing its consequences and improving the quality of life of patients.

\section{Acknowledgments}

None.

\section{Conflicts of interest}

The authors declare that there is no conflict of interest.

\section{References}

1. World Cancer Report: Cancer Research for Cancer Prevention. Lyon, France: International Agency for Research on Cancer; 2020.

2. INCA/Ministério da Saúde. Estimativa 2020: incidência de câncer no Brasil. Instituto Nacional de Câncer José Alencar Gomes da Silva/ Ministério da Saúde; 2019.

3. Bray F, Ferlay J, Soerjomataram I, et al. Global cancer statistics 2018: GLOBOCAN estimates of incidence and mortality worldwide for 36 cancers in 185 countries. CA Cancer J Clin. 2018;68(6):394-424.

4. Yamada SI, Soutome S, Hasegawa T, et al. A multicenter retrospective investigation on the efficacy of perioperative oral management in cancer patients. Medicine (Baltimore). 2020;99(10):e19129.

5. Nobuhara H, Yanamoto S, Funahara M, et al. Effect of perioperative oral management on the prevention of surgical site infection after colorectal cancer surgery: A multicenter retrospective analysis of 698 patients via analysis of covariance using propensity score. Med (United States). 2018;97(40):e12545.

6. Zecha JAEM, Raber-Durlacher JE, Laheij AMGA, et al. The impact of the oral cavity in febrile neutropenia and infectious complications in patients treated with myelosuppressive chemotherapy. Support Care Cancer. 2019;27(10):3667-3679.

7. Acosta-Galeano MF, Jacquett-Toledo NL. Importancia del odontólogo dentro del plantel multidisciplinario de oncología. Mem Inst Invest Cienc Salud. 2017;15(3):93-98. 
8. Kowlessar A, Naidu R, Ramroop V, et al. Oral health among children attending an oncology clinic in Trinidad. Clin Exp Dent Res. 2019;5(6):665-669.

9. Marur S, Forastiere AA. Head and Neck Squamous Cell Carcinoma: Update on Epidemiology, Diagnosis, and Treatment. Mayo Clin Proc. 2016;91(3):386-396.

10. Alfouzan AF. Review of surgical resection and reconstruction in head and neck cancer: Traditional versus current concepts. Saudi Med J. 2018;39(10):971-980.

11. Leitão BFB, Duarte ÍV, Bettega PB. Pacientes com câncer de cavidade bucal submetidos à cirurgia: representações sociais acerca do adoecimento e tratamento. Rev da SBPH. 2013;16(1):113-140.

12. Paiva MDEB, Biase R de CCG de, Moraes JJ de C, et al. Complicações orai decorrentes da terapia antineoplásica. Arq em Odontol. 2010;46(1):48-55.

13. Alberga J, Vosselman N, Korfage A, et al. What is the optimal timing for implant placement in oral cancer patients? A scoping literature review. Oral Dis. 2020;27(1):94-110.

14. Genden EM, Okay D, Stepp MT, et al. Comparison of functional and quality-of-life outcomes in patients with and without palatomaxillary reconstruction: A preliminary report. Arch Otolaryngol-Head Neck Surg. 2003;129(7):775-780.

15. Wong TSC, Wiesenfeld D. Oral Cancer. Aust Dent J. 2018;63(Suppl 1):S91-S99.

16. Joshi VK. Dental treatment planning and management for the mouth cancer patient. Oral Oncol. 2010;46(6):475-479.

17. Depprich R, Naujoks C, Lind D, et al. Evaluation of the quality of life of patients with maxillofacial defects after prosthodontic therapy with obturator prostheses. Int J Oral Maxillofac Surg. 2011;40(1):71-79.

18. Goiato MC, Pesqueira AA, Silva CR da, et al. Patient satisfaction with maxillofacial prosthesis. Literature review. J Plast Reconstr Aesthetic Surg. 2009;62(2):175-180.

19. Kusterer L, Paraguassú G, Silva V, Sarmento V. Reabilitação com obturador maxilar após cirurgia oncológica: relato de casos. Rev Cir e Traumatol Buco-maxilo-facial. 2012;12(4):9-16.

20. Pace-Balzan A, Rogers SN. Dental rehabilitation after surgery for ora cancer. Curr Opin Otolaryngol Head Neck Surg. 2012;20(2):109-113.

21. Petrovic I, Rosen EB, Matros E, et al. Oral rehabilitation of the cancer patient: A formidable challenge. J Surg Oncol. 2018;117(8):1729-1735.

22. Jham BC, Freire AR da S. Oral complications of radiotherapy in the head and neck Summary. Braz J Otorhinolaryngol. 2006;72(5):704-708.

23. Schuurhuis JM, Stokman MA, Roodenburg JLN, et al. Efficacy of routine pre-radiation dental screening and dental follow-up in head and neck oncology patients on intermediate and late radiation effects. A retrospective evaluation. Radiother Oncol. 2011;101(3):403-409.

24. Freitas DA, Caballero AD, Pereira MM, et al. Efeitos Adversos Da Radioterapia De Cabeça E Pescoço. Rev CEFAC. 2011;13(6):1103-1108.

25. Strojan P, Hutcheson KA, Eisbruch A, et al. Treatment of late sequelae after radiotherapy for head and neck cancer. Cancer Treat Rev. 2017;59:79-92.

26. Iqbal MS, Chaw C, Kovarik J, et al. Primary concurrent chemoradiation in head and neck cancers with weekly cisplatin chemotherapy: Analysis of compliance, toxicity and survival. Int Arch Otorhinolaryngol. 2017;21(2):171-177

27. Sroussi HY, Epstein JB, Bensadoun RJ, et al. Common oral complications of head and neck cancer radiation therapy: mucositis, infections, saliva change, fibrosis, sensory dysfunctions, dental caries, periodontal disease, and osteoradionecrosis. Cancer Med. 2017;6(12):2918-2931.
28. Jawad H, Hodson NA, Nixon PJ. A review of dental treatment of head and neck cancer patients, before, during and after radiotherapy: Part 2. $\mathrm{Br}$ Dent J. 2015;218(2):69-74.

29. Hovan AJ, Williams PM, Stevenson-Moore P, et al. A systematic review of dysgeusia induced by cancer therapies. Support Care Cancer. 2010;18(8):1081-1087.

30. Brennan MT, Treister NS, Sollecito TP, et al. Dental disease before radiotherapy in patients with head and neck cancer. $J$ Am Dent Assoc. 2017;148(12):868-877.

31. Høxbroe Michaelsen S, Grønhøj C, Høxbroe Michaelsen J, et al. Quality of life in survivors of oropharyngeal cancer: A systematic review and meta-analysis of 1366 patients. Eur J Cancer. 2017;78:91-102.

32. Jensen SB, Pedersen AML, Vissink A, et al. A systematic review of salivary gland hypofunction and xerostomia induced by cancer therapies: Prevalence, severity and impact on quality of life. Support Care Cancer. 2010;18(8):1039-1060

33. Sonis ST. Oral Mucositis in Head and Neck Cancer: Risk, Biology, and Management. Am Soc Clin Oncol Educ Book. 2013;33:e236-240.

34. Jensen SB, Vissink A, Limesand KH, et al. Salivary Gland Hypofunction and Xerostomia in Head and Neck Radiation Patients. J Natl Cancer Inst Monogr. 2019;2019(53):lgz016.

35. Albuquerque RA de, Morais VLL de, Sobral APV. Protocolo de atendimento odontológico a pacientes oncológicos pediátricos-revisão de literatura. Rev Odontol da UNESP. 2007;36(3):275-280.

36. Caccelli ÉMN, Rapport A. Para-efeitos das irradiações nas neoplasias de boca e orofaringe. Rev Bras Cir Cabeça e Pescoço. 2008;37(4):198-201.

37. Kielbassa AM, Hinkelbein W, Hellwig E, et al. Radiation-related damage to dentition. Lancet Oncol. 2006;7(4):326-335.

38. Santos CC, Noro-Filho GA, Caputo BV, de Souza RC, et al. Condutas práticas e efetivas recomendadas ao cirurgião dentista no tratamento pré, trans e pós do câncer bucal. J Heal Sci Inst. 2013;31(4):368-372.

39. Bensadoun RJ, Riesenbeck D, Lockhart PB, et al. A systematic review of trismus induced by cancer therapies in head and neck cancer patients. Support Care Cancer. 2010;18(8):1033-1038.

40. Hong CHL, Hu S, Haverman T, et al. A systematic review of dental disease management in cancer patients. Support Care Cancer. 2018;26(1):155174.

41. Peterson DE, Doerr W, Hovan A, et al. Osteoradionecrosis in cancer patients: The evidence base for treatment-dependent frequency, current management strategies, and future studies. Support Care Cancer. 2010;18(8):1089-1098.

42. INCA/Ministério da Saúde. ABC do câncer: abordagens básicas para o controle do câncer. Vol. 81. Instituto Nacional de Câncer José Alencar Gomes da Silva; 2011. 1-2 p.

43. Hartner L. Chemotherapy for Oral Cancer. Dent Clin North Am. 2018;62(1):87-97.

44. Petrelli F, Barni S. Anti-EGFR-targeting agents in recurrent or metastatic head and neck carcinoma: A meta-analysis. Head Neck. 2012;34(11):16571664

45. Winquist E, Al-Rasheedy I, Nichols AC, et al. Temporal changes in the efficacy of chemotherapy for recurrent or metastatic squamous cell carcinoma of the head and neck: a systematic review and meta-analysis. Cancer Treat Rev. 2014;40(9):1073-1079.

46. Antunes HS, Crelier AC, Ribeiro AA, et al. Como o cirurgião dentista deve atender o paciente oncológico? Rev Int Estomatol. 2004;1(1):30-38. 
47. Hespanhol FL, Tinoco EMB, Teixeira HG de C, et al. Manifestações bucais em pacientes submetidos à quimioterapia. Cienc e Saude Coletiva. 2010;15(Suppl 1):1085-1094.

48. Lalla RV, Bowen J, Barasch A, et al. MASCC/ISOO clinical practice guidelines for the management of mucositis secondary to cancer therapy. Cancer. 2014;120(10):1453-1461.

49. Ortíz-Rubio A, López-Verdín S, Ochoa-Velazquez H. Manejo odontológico de las complicaciones orales como resultado de la terapia contra el cáncer. Rev ADM. 2016;73(1):6-10.

50. Wani V, Kulkarni A, Pustake B, et al. Prevalence, complications and dental management of the oral cancer in the pediatric patients. $J$ Cancer Res Ther. 2018;14(6):1407-1411.

51. Elad S, Raber-Durlacher JE, Brennan MT, et al. Basic oral care for hematology-oncology patients and hematopoietic stem cell transplantation recipients: a position paper from the joint task force of the Multinational Association of Supportive Care in Cancer/International Society of Oral Oncology (MASCC/ISOO) and the European Society for Blood and Marrow Transplantation (EBMT). Support Care Cancer. 2015;23(1):223-236.

52. Chaveli-López B, Bagán-Sebastián JV. Treatment of oral mucositis due to chemotherapy. J Clin Exp Dent. 2016;8(2):e201-209.

53. Villa A, Akintoye SO. Dental Management of Patients Who Have Undergone Oral Cancer Therapy. Dent Clin North Am. 2018;62(1):131142 .

54. Rugo HS, Seneviratne L, Beck JT, et al. Prevention of everolimus-related stomatitis in women with hormone receptor-positive, HER2-negative metastatic breast cancer using dexamethasone mouthwash (SWISH): a single-arm, phase 2 trial. Lancet Oncol. 2017;18(5):654-662.

55. Vigarios E, Epstein JB, Sibaud V. Oral mucosal changes induced by anticancer targeted therapies and immune checkpoint inhibitors. Support Care Cancer. 2017;25(5):1713-1739.

56. Owosho AA, Xu B, Kadempour A, et al. Metastatic solid tumors to the jaw and oral soft tissue: A retrospective clinical analysis of 44 patients from a single institution. J Cranio-Maxillofacial Surg. 2016;44(8):1047-1053.

57. Andabak Rogulj A, Tomasovic Loncaric C, Muller D, et al. Solid malignant metastases in the jaw bones. Br J Oral Maxillofac Surg. 2018;56(8):705-708.

58. Irani S. Metastasis to the Jawbones: A review of 453 cases. J Int Soc Prev Community Dent. 2017;7(2):71-81.

59. Kalaitsidou IG, Astreidis IT, Kontos KI, et al. Metastatic Tumours to the Oral Cavity: Report of Three Cases. J Oral Maxillofac Res. 2015;6(4):e5.

60. Copelan EA. Hematopoietic stem-cell transplantation. $N$ Engl J Med. 2006;354(17):1813-1826.

61. Armitage JO. Bone Marrow Transplantation. $N$ Engl $J$ Med. 1994;330(12):827-838

62. Castro Jr CG de, Gregianin LJ, Brunetto AL. Transplante de medula óssea e transplante de sangue de cordão umbilical em pediatria. J Pediatr (Rio J). 2001;77(5):345-360.

63. van Leeuwen SJM, Potting CMJ, Huysmans MCDNJM, et al. Salivary Changes before and after Hematopoietic Stem Cell Transplantation: A Systematic Review. Biol Blood Marrow Transplant. 2019;25(6):10551061.

64. Barrach RH, de Souza MP, Da Silva DPC, et al. Oral changes in individuals undergoing hematopoietic stem cell transplantation. Braz J Otorhinolaryngol. 2015;81(2):141-147.

65. Jagasia MH, Greinix HT, Arora M, et al. National Institutes of Health Consensus Development Project on Criteria for Clinical Trials in Chronic Graft-versus-Host Disease: I. The 2014 Diagnosis and Staging Working Group Report. Biol Blood Marrow Transplant. 2015;21(3):389-401.e1.
66. Santos PSS, Rubira CMF, Antunes HS, et al. Oral graft vs host disease: An immune system disorder in hematopoietic cell transplantation. World J Stomatol. 2015;4(2):96-102.

67. Lee SJ, Wolff D, Kitko C, et al. Measuring Therapeutic Response in Chronic Graft-Versus-Host Disease. Biol Blood Marrow Transpl. 2015;21(6):984-999.

68. Atsuta Y, Suzuki R, Yamashita T, et al. Continuing increased risk of oral/ esophageal cancer after allogeneic hematopoietic stem cell transplantation in adults in association with chronic graft-versus-host disease. Ann Oncol. 2014;25(2):435-441.

69. Rizzo JD, Curtis RE, Deeg HJ, et al. Response: Solid cancers after allogeneic hematopoietic cell transplantation. Blood. 2009;114(1):225226.

70. Danylesko I, Shimoni A. Second Malignancies after Hematopoietic Stem Cell Transplantation. Curr Treat Options Oncol. 2018;19(2):9.

71. Majhail NS, Rizzo JD, Lee SJ, et al. Recommended Screening and Preventive Practices for Long-Term Survivors after Hematopoietic Cell Transplantation. Bone Marrow Transplant. 2012;47(3):348-371.

72. Antunes HS, Caldas RJ, Granzotto FCN, et al. Medication-related osteonecrosis of the jaw. Rev Bras Odontol. 2018;75:1.

73. Di Fede O, Panzarella V, Mauceri R, et al. The dental management of patients at risk of medication-related osteonecrosis of the jaw: New paradigm of primary prevention. Biomed Res Int. 2018;2018:2684924.

74. Reid IR. Osteonecrosis of the jaw - Who gets it, and why? Bone. 2009;44(1):4-10.

75. American Dental Association Council on Scientific Affairs. Dental management of patients receiving oral bisphosphonate therapy. J Am Dent Assoc. 2006;137(8):1144-1150.

76. Fleisch H. Bisphosphonates: Mechanisms of Action. Endocr Rev. 1998;19(1):80-100.

77. Ruggiero SL, Dodson TB, Fantasia J, et al. American association of oral and maxillofacial surgeons position paper on medication-related osteonecrosis of the jaw - 2014 update. J Oral Maxillofac Surg. 2014;72(10):1938-1956.

78. Smith SJ, AlQranei M, Alagl AS, et al. Tooth Extraction Protocols for Patients on Bisphosphonate Therapy: An Update. J Int Acad Periodontol. 2017;20(1):38-47.

79. Shaw MJ, Kumar NDK, Duggal M, et al. Oral management of patients following oncology treatment: Literature review. Br J Oral Maxillofac Surg. 2000;38(5):519-524.

80. Usubuchi M, Matsuura K, Goto T, et al. Professional Oral Health Care at General Dental Clinic Reduces Postoperative Complications of Head and Neck Free-Flap Reconstruction Surgery. J Cancer. 2019;10(1):205-210.

81. Ishimaru M, Matsui H, Ono S, et al. Preoperative oral care and effect on postoperative complications after major cancer surgery. $\mathrm{Br} J \mathrm{Surg}$. 2018;105(12):1688-1696.

82. Keys M, Mccasland JP. Techniques and results of a comprehensive dental care program in head and neck cancer patients. Int J Radiat Onology Biol Phys. 1976;1(9-10):859-865.

83. Butterworth C, McCaul L, Barclay C. Restorative dentistry and oral rehabilitation: United Kingdom National Multidisciplinary Guidelines. $J$ Laryngol Otol. 2016;130(S2):S41-S44.

84. Epstein JB, Güneri P, Barasch A. Appropriate and necessary oral care for people with cancer: guidance to obtain the right oral and dental care at the right time. Support Care Cancer. 2014;22(7):1981-1988.

85. Jawad H, Hodson NA, Nixon PJ. A review of dental treatment of head and neck cancer patients, before, during and after radiotherapy: Part 1. $\mathrm{Br}$ Dent J. 2015;218(2):69-74. 
86. Schuurhuis JM, Stokman MA, Witjes MJH, et al. Patients with advanced periodontal disease before intensity-modulated radiation therapy are prone to develop bone healing problems: a 2-year prospective follow-up study. Support Care Cancer. 2018;26(4):1133-1142.

87. Beech N, Robinson S, Porceddu S, et al. Dental management of patient irradiated for head and neck cancer. Aust Dent J. 2014;59(1):20-28.

88. Jansma J, Vissink A, Spijkervet FKL, et al. Protocol for the prevention and treatment of oral sequelae resulting from head and neck radiation therapy. Cancer. 1992;70(8):2171-2180.

89. Cox FL. Endodontics and the irradiated patient. Oral Surgery, Oral Med Oral Pathol. 1976;42(5):679-684.

90. Levi LE, Lalla RV. Dental Treatment Planning for the Patient with Oral Cancer. Dent Clin North Am. 2018;62(1):121-130.

91. Ion D, Stevenson K, Woo SB, et al. Characterization of Oral Involvement in Acute Graft-versus-Host Disease. Biol Blood Marrow Transplant. 2014;20(11):1717-1721.

92. Jham BC, Reis PM, Miranda EL. Oral health status of 207 head and neck cancer patients before, during and after radiotherapy. Clin Oral Invest. 2008;12(1):19-24.

93. White JM, Panchal NH, Wehler CJ, et al. Department of Veterans Affairs Consensus: Preradiation dental treatment guidelines for patients with head and neck cancer. Head Neck. 2019;41(5):1153-1160.

94. Fujii H, Hirose C, Ishihara M, et al. Improvement of dysgeusia by polaprezinc, a Zinc-L-Carnosine, in outpatients receiving cancer chemotherapy. Anticancer Res. 2018;38(11):6367-6373.

95. Antunes HS, Herchenhorn D, Small IA, et al. Phase III trial of lowlevel laser therapy to prevent oral mucositis in head and neck cancer patients treated with concurrent chemoradiation. Radiother Oncol. 2013;109(2):297-302.

96. Saunders DP, Rouleau T, Cheng K, et al. Systematic review of antimicrobials, mucosal coating agents, anesthetics, and analgesics for the management of oral mucositis in cancer patients and clinical practice guidelines. Support Care Cancer. 2020;28(5):2473-2484.

97. Carpenter PA, Kitko CL, Elad S, et al. National Institutes of Health Consensus Development Project on Criteria for Clinical Trials in Chronic Graft-versus-Host Disease: V. The 2014 Ancillary Therapy and Supportive Care Working Group Report. Biol Blood Marrow Transplant. 2015;21(7):1167-1187.
98. Lyons A, Ghazali N. Osteoradionecrosis of the jaws: current understanding of its pathophysiology and treatment. $\mathrm{Br} J$ Oral Maxillofac Surg. 2008;46(8):653-660.

99. McLeod NMH, Pratt CA, Mellor TK, et al. Pentoxifylline and tocopherol in the management of patients with osteoradionecrosis, the Portsmouth experience. Br J Oral Maxillofac Surg. 2012;50(1):41-44.

100. Santos R, Dall'Magro AK, Giacobbo J, et al. Osteorradionecrose em pacientes submetidos à radioterapia de cabeça e pescoço: relato de caso. Rev da Fac Odontol-UPF. 2015;20(2):232-237.

101. Dhanda J, Hall TJH, Wilkins A, et al. Patterns of treatment of osteoradionecrosis with hyperbaric oxygen therapy in the United Kingdom. Br J Oral Maxillofac Surg. 2009;47(3):210-213.

102. Nolen D, Cannady SB, Wax MK, et al. Comparison of complications in free flap reconstruction for osteoradionecrosis in patients with or without hyperbaric oxygen therapy. Head Neck. 2014;36(12):1701-1704.

103. Robard L, Louis MY, Blanchard D, et al. Medical treatment of osteoradionecrosis of the mandible by PENTOCLO: Preliminary results. Eur Ann Otorhinolaryngol Head Neck Dis. 2014;131(6):333-338.

104. Cunha SR de B da, Ramos PAM, Nesrallah ACA, et al. The Effects of Ionizing Radiation on the Oral Cavity. J Contemp Dent Pract. 2015;16(8):679-687.

105. Barker GJ. Current practices in the oral management of the patient undergoing chemotherapy or bone marrow transplantation. Support Care Cancer. 1999;7(1):17-20.

106. Demian NM, Shum JW, Kessel IL, et al. Oral surgery in patients undergoing chemoradiation therapy. Oral Maxillofac Surg Clin North Am. 2014;26(2):193-207.

107. López BC, Esteve CG, Pérez MGS. Dental treatment considerations in the chemotherapy patient. J Clin Exp Dent. 2011;3(1):e31-42.

108. Ahn JW, Shalabi D, Correa-Selm LM, et al. Impaired wound healing secondary to bevacizumab. Int Wound J. 2019;16(4):1009-1012. 